\title{
Growth response to thinning in Quercus pyrenaica Willd. coppice stands in Spanish central mountain
}

\author{
Isabel CAÑEllas*, Miren Del Río, Sonia RoIG, Gregorio MonTERo \\ Centre for Forest Research - INIA, Ctra. A Coruña km 7,5, Madrid 28040, Spain
}

(Received 10 March 2003; accepted 17 June 2003)

\begin{abstract}
This paper presents the growth response of coppice forest of Quercus pyrenaica Willd. to thinnings of different intensities. Four treatments were tested: light, moderate and heavy thinning with respectively 25,35 and $50 \%$ of basal area removed, and no thinning (control). The results obtained show significant differences between treatments for diameter and biomass of the mean tree and for current diameter increment, for the three inventories carried out $(1994,1998,2002)$. The largest values for the mean tree were observed with the heaviest thinning treatment. No differences were found between treatments for stand yield (total basal area and biomass). Stand structure appears more regular in thinned plots, reducing the risk of forest fires and increasing the landscape and recreation values and the possibility of silvopastoral use.
\end{abstract}

growth / Mediterranean oak / stand structure / thinning / coppice

Résumé - Croissance de taillis de chêne tauzin (Quercus pyrenaica Willd.) soumis à différentes intensités d'éclaircie dans la chaîne montagneuse centrale de l'Espagne. Cet article présente la réponse de taillis de chêne tauzins (Quercus pyrenaica Willd.) à des éclaircies par le bas de différentes intensités. Au total, quatre traitements ont été appliqués: éclaircie faible, moyenne et forte en enlevant respectivement 25, 35 et $50 \%$ de la surface terrière et un traitement sans éclaircie (contrôle). Les résultats ont mis en évidence des écarts significatifs en ce qui concerne le diamètre et la biomasse de l'arbre moyen et l'accroissement courant du diamètre aux trois dates d'inventaires pratiqués (1994, 1998, 2002): à chacun de ces inventaires, des valeurs plus importantes ont été obtenues pour l'arbre moyen lorsque l'intensité d'éclaircie était la plus forte. Aucun écart significatif entre traitements n'a été observé en ce qui concerne la production totale (surface terrière et biomasse). La structure du peuplement est plus régulière dans les parcelles éclaircies, réduisant par là-même les risques d'incendies et augmentant la valeur paysagère et récréative des peuplements ainsi que leur aptitude au sylvo-pastoralisme.

croissance / chêne tauzin / éclaircie / structure du peuplement / taillis

\section{INTRODUCTION}

Due to rural development, spectacular changes in land uses have been affecting numerous regions of Europe in recent decades, particularly in mountain areas and in Mediterranean countries. Nowadays, management of the extensive areas of Quercus species coppices is one of the largest problems that forestry research is facing in Mediterranean countries. In the past, these stands were managed as coppice or coppice with standards by cutting trees every 20 years with subsequent shoot or root regeneration. They had a prominent place within the traditional economy of Mediterranean regions, as providers of firewood, charcoal, fuel for glass making, products such as tannin, and also by providing grazing areas for livestock, primarily sheep and cows. This treatment was progressively abandoned due to the decrease in use of firewood and charcoal as an energy source. As a result of the lack of management, these stands show now severe ecological, economic and social constraints such as high tree densities, almost no seed regeneration, stand decay, and loss of economic and social benefits, etc., which may endanger the existence of Quercus stands in the long run. At the driest and lowest quality sites, there is a stagnation in growth, and one of the greatest risks for these coppice is their destruction by forest fires [28].

The recognition of these problems in such wide areas, and the increasing interest in implementing direct and indirect production uses for these stands (silvopastoral uses, recreation, environmental preservation) justify the urgent need to study and manage them $[25,26]$. Several studies throughout the Mediterranean area $[2,3,7,9,17,20]$ led to possible alternatives to the current coppice situation, from the abandonment of silvicultural practices to a more intense level of management: reforestation, agricultural uses, establishment of pastures, new coppice systems, conversion to open woodlands, transformation

\footnotetext{
*Corresponding author: canellas@inia.es
} 
to high forest, etc. Quercus pyrenaica, $Q$. faginea Lam. and $Q$. ilex L. seem to respond better to the two last alternatives in Spanish conditions $[3,4,23,28]$.

Quercus pyrenaica Willd. (rebollo oak) covers an area of 659000 ha in Spain. Research about its ecological and productive values, in order to enable suitable decisions about its sustainable and potential uses, is necessary due to the large cover and the current abandonment of these stands, as for many Quercus species in the Mediterranean region. The Centre for Forest Research (CIFOR-INIA) planned a set of thinning experiments to transform the structure of $Q$. pyrenaica coppice, focusing on various aspects: stand structure and production, litter-fall, shoot production, acorn production, herbaceous vegetation, etc. $[3,25,30,31]$. The main objective of this work was to analyse the effect of thinning on growth and development at individual and stand level in a $Q$. pyrenaica coppice.

\section{MATERIALS AND METHODS}

The experimental trial was carried out on a $Q$. pyrenaica stand in Rascafría (Central mountain range of Spain), on a 30\% Southeast facing slope, at $1350 \mathrm{~m}$ a.s.1., ( $40^{\circ} 54^{\prime} \mathrm{N}$ latitude, $3^{\circ} 51^{\prime} \mathrm{W}$ longitude). Annual rainfall there is $1037 \mathrm{~mm}$ and the soil type is a humic cambisol. Potential vegetation corresponds to Luzulo forsteri-Quercetum pyreniacae [22] and actual vegetation type was a 30 years-old one-storied $Q$. pyrenaica coppice.

The thinning experiment was carried out during the winter of 1994. Four treatments were tested: A- Control; C- light thinning (25\% of basal area removal); D- moderate thinning (35\%) and E- heavy thinning (50\%). According to the terminology used by Assmann [1] in thinning experiments developed in European forests, the thinning type was from low, eliminating small trees, trees with badly shaped crowns, twisted stems, diseased trees, etc.

The experiment was implemented according to a completely random design with four treatments and two replications. The squared size treatment plot was $1600 \mathrm{~m}^{2}$. At the beginning of the experiment, all the standing stems were included in the inventory and all stems were permanently numbered. In each plot, the following measurements were made: diameter at breast height $(d b h, \mathrm{~cm})$ for all living stems, and total height for a permanent sample of 40 trees covering the full dbh range. Measurement inventories were carried out every 4 years after the thinning (1994, 1998 and 2002).

Total biomass (wood plus bark of the trunk and branches) for each stem was estimated for each inventory through an allometric regression with dbh as independent variable. This equation was derived from a sample of 132 trees of this $Q$. pyrenaica forest, distributed over the same $d b h$ range (at least 10 trees of each diameter class of $5 \mathrm{~cm}$ ). The regression equation was the following:

$$
B t=0.0575 \cdot d b h^{2.6695} \quad \mathrm{R}^{2}=0.972,
$$

where $B t$ is the total stem biomass in $\mathrm{kg}$ (dry weight) and $d b h$ is the diameter at $1.30 \mathrm{~m}$ in $\mathrm{cm}$. This equation was fitted after logarithmic transformations by lineal methods, taking into account the correction factors proposed by Flewelling and Pienaar [14] to large sample size. The biomass of mean tree $(\mathrm{Bm})$ by plot was calculated by following expressions:

$$
B m=\frac{1}{n} \sum_{1}^{n} B t_{i},
$$

where $n$ is the number of trees by plot.

Linear regression equations (after logarithmic transformation) were fitted for each plot to estimate individual tree height [14]:

$$
h=a \cdot d b h^{b},
$$

where $h$ is tree height (m), $d b h$ is diameter at breast height $(\mathrm{cm}), a$ and $b$ are parameters. Correction factors were taking into account to reduce the possible bias due logarithmic transformation [14].

Effects of thinning on stem diameter growth rates over the whole study period were tested by an analysis of covariance of individual growth rates using initial stem diameter $(d b h)$ as a covariate.

Time-dependence of tree and stand growth rates were tested by repeated measurement analysis of variance [21,27]:

$$
Y_{l}=\mu+T+\varepsilon_{l},
$$

where $Y_{1}=\left\{Y_{11}, Y_{21}\right\}$ are the observed measurements on a stem at the two growth periods, $\mu=\left\{\mu_{1}, \mu_{2}\right\}$ are the corresponding population mean values for the two dates and $T$ is treatment vector. $\varepsilon_{1} \sim \mathrm{N}(0$, $\left.\operatorname{cov}\left(\varepsilon_{1}, \varepsilon_{1}^{\prime}\right)\right)$ means that the errors are normal multivariate with common covariance matrix among stems. Mauchly's criterion test for the compound symmetry of the variance-covariance matrix was obtained. As the hypothesis of symmetry assumption was rejected, the multivariate approach that does not require the sphericity condition was selected $[21,27]$. The null hypothesis of no time effect, $\mu 1=\mu 2$, states that the mean growth response is the same for each of two growth periods.

Although the ecological and dendrometrical characteristics of the plots seemed very similar, an analysis of variance was developed with the data of the first inventory to analyse possible differences between plots for the main stand variables before the thinning (mean diameter, mean height and number of stems per hectare). Similar analyses were carried out for the main crop after thinning and for the second and the third inventories. The model used in the analysis of variance (ANOVA) was the following [27]:

$$
Y_{i}=\mu+T_{i}+e_{i},
$$

where $Y_{i}$ is variable analised, $\mu$ is the overall mean effect, $T_{i}$ is the effect of thinning and $\mathrm{e}_{\mathrm{i}}$ are assumed independently, with random distribution. Duncan's test of multiple range was used to analyse the differences among treatments for the main stand variables (95\% of significance level).

\section{RESULTS}

\subsection{Tree growth}

Mean absolute diameter increment during the whole interval 1994-2002 was $2.11 \mathrm{~mm} \mathrm{yr}^{-1}$ for thinned plots and $0.99 \mathrm{~mm} \mathrm{yr}^{-1}$ for unthinned plots. The time dependence of the above effect can be addressed by analysing separately the data for the period 1994-1998 (four years after thinning) and 1998-2002 (eight years after thinning) as shown in Table I.

A repeated measures analysis of variance was used to evaluate significant differences through time and those due to treatment (thinned or unthinned). Both time and treatments had a significant effect $(P<0.001)$. An interaction between treatment and time was also found to be significant. This means that the effect of time (date of inventory) is different for the four treatments overall, between stronger thinned plots and controls plots. Stem diameter increments were higher for thinned than for unthinned plots and were higher in the second period (19982002) than in the first one (1994-1998). Figure 1 shows the mean diameter increment of trees for each period and each treatment. Heavy and moderate thinning increased mean stem diameter increment by $157 \%$ compared to unthinned plots during the first period and by $126 \%$ during the second one. However, light thinning (C) presents lower differences with the control for the first interval $(35 \%)$ than for the second one $(81 \%)$. 
Table I. Mean and standard deviation (in bracket) absolute and relative stem diameter increment of $Q$. pyrenaica trees in unthinned and thinned treatments ( $\mathrm{C}$ - light thinning; D - moderate thinning; $\mathrm{E}$ - heavy thinning).

\begin{tabular}{|c|c|c|c|}
\hline \multirow{2}{*}{ Treatments } & \multicolumn{3}{|c|}{ Period } \\
\hline & 1994-1998 & 1998-2002 & 1994-2002 \\
\hline \multicolumn{4}{|c|}{ Mean absolute diameter increment $\left(\mathrm{mm}\right.$ year $\left.{ }^{-1}\right)$} \\
\hline Unthinned & $0.84(0.19)$ & $1.12(0.08)$ & $0.99(0.06)$ \\
\hline Thinned C & $1.13(0.29)$ & $2.03(0.21)$ & $1.58(0.04)$ \\
\hline Thinned D & $1.99(0.30)$ & $2.32(0.339$ & $2.16(0.01)$ \\
\hline Thinned E & $2.33(0.18)$ & $2.74(0.34)$ & $2.59(0.09)$ \\
\hline \multicolumn{4}{|c|}{ Mean relative diameter increment $\left(\%\right.$ year $\left.^{-1}\right)$} \\
\hline Unthinned & $0.82(0.22)$ & $0.97(0.02)$ & $0.90(0.10)$ \\
\hline Thinned C & $0.92(0.24)$ & $1.59(0.23)$ & $1.25(0.01)$ \\
\hline Thinned D & $1.74(0.40)$ & $1.83(0.16)$ & $1.79(0.12)$ \\
\hline Thinned E & $1.84(0.17)$ & $2.00(0.25)$ & $1.92(0.04)$ \\
\hline
\end{tabular}

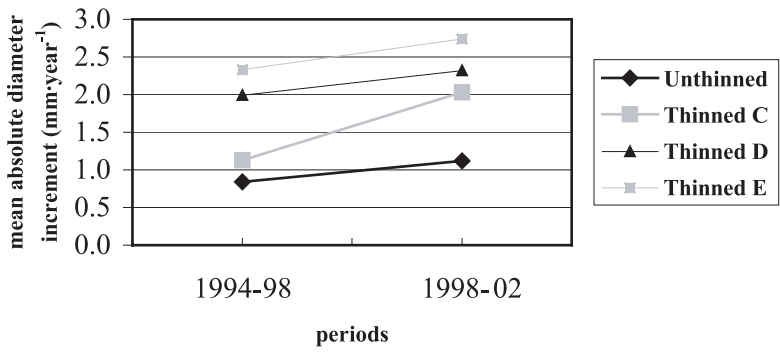

Figure 1. Mean absolute diameter increment $\left(\mathrm{mm} \mathrm{year}^{-1}\right)$ by treatments and growth periods.

The results of Ducan's test also explain the aforementioned different responses to thinning intensities in the two growth intervals (Tab. II). This fact seems to indicate a slower response to light thinning.

Absolute increments $\left(\mathrm{mm}\right.$ year $\left.^{-1}\right)$ of the stem diameter of individual trees during the first interval after thinning were only slightly and positive correlated significantly with initial stem diameter, both in thinned and unthinned plots. On average, the large trees (diameter $>15 \mathrm{~cm}$ ) had absolute growth rates higher than smaller ones (diameter $<15 \mathrm{~cm}$ ) by $150 \%$. A covariance analysis was performed to test whether thinning still had a significant effect on diameter growth after taking account of the effect of initial dbh, and whether there was a significant interaction between thinning and initial diameter. The model included terms for treatment and initial diameter as a covariant. The results showed that initial diameter and interaction term had a significant effect $(P<0.0001)$ on the absolute diameter increment in the two intervals and for the total period.

The effect of initial stem diameter on growth can also be studied through the relative diameter growth $(r d g)$ for each tree, defined as the percentage of absolute individual diameter increment in a given period divided by the diameter at the beginning of the period [20]:

$$
r d g 21=\frac{d g 2-d g 1}{d g 1} \cdot 100,
$$

where $d g$ is the squared mean diameter for each tree.
Table II. Duncan's test of differences among current increment of quadratic diameter $(I c d g)$, relative increment of quadratic diameter $(r d g)$. Treatments: A - control; C - light thinning; D - moderate thinning; E - heavy thinning.

\begin{tabular}{lcc}
\hline \multirow{2}{*}{ Variables } & \multicolumn{2}{c}{ Inventories $^{1}$} \\
\cline { 2 - 3 } & $1994-1998$ & $1998-1002$ \\
\hline$I c d g$ & E D $\underline{\mathrm{CA}}^{*}$ & $\mathrm{E} \mathrm{D} \mathrm{C} \mathrm{T} *$ \\
$r d g$ & $\mathrm{E} \mathrm{D} \underline{\mathrm{CA}}^{*}$ & $\mathrm{E} \mathrm{D} \mathrm{C} \mathrm{T}$
\end{tabular}

${ }^{1}$ Underline means there are not significant differences between treatments; * significant at 5\%; the treatments order is given by Duncan's test.

Mean relative diameter increments $(r D g)$ during the first interval after thinning were $0.82 \%$ and $1.5 \%$ in unthinned and thinned plots respectively, and $0.97 \%$ and $1.8 \%$ in the second interval (Tab. I). Significant differences in mean relative diameter increments were found in the repeated measures analyses of variance through time and between treatments, showing a similar behaviour to absolute increment. This analysis corroborates the positive effect of thinning on diameter growth in this coppice stand (Tab. II).

A repeated measures analysis of variance was used to evaluate significant differences through time and those due to treatment in height growth too. There were no differences $(P>0.05)$ in height growth between treatments or time. The same results were obtained with a covariance analysis considering the initial height of the tree as covariant.

\subsection{Stand development and structure}

The main stand variables per plot at the beginning of the experiment and the evolution of the means per treatment of the main stand variables after thinning, of natural mortality and of total stand production are presented in Tables III and IV respectively. The high reduction of number of trees in treatments $\mathrm{D}$ and $\mathrm{E}$ results from the intensive thinnings performed in these treatments $(50 \%$ of initial basal area removed for treatment $\mathrm{E}$ 
Table III. Main stand variables per plot at the beginning of the experiment (30-years-old): C - light thinning; D - moderate thinning; E heavy thinning.

\begin{tabular}{|c|c|c|c|c|c|c|c|c|c|}
\hline \multirow{2}{*}{ Treatment } & \multicolumn{6}{|c|}{ Stand before thinning } & \multicolumn{3}{|c|}{ Stand removed } \\
\hline & $N$ & $D g$ & $H g$ & $G$ & $B m$ & $B T$ & $N$ & $G$ & $B T$ \\
\hline Unthinned & 4506 & 10.1 & 7.6 & 36.4 & 31.8 & 143.4 & & & \\
\hline Unthinned & 4144 & 10.6 & 7.8 & 36.8 & 36.4 & 150.8 & & & \\
\hline Thinned C & 4869 & 9.4 & 8.7 & 33.5 & 26.0 & 126.5 & 2813 & 8.6 & 23.1 \\
\hline Thinned C & 4506 & 9.5 & 8.8 & 32.2 & 27.6 & 124.2 & 2681 & 8.7 & 23.2 \\
\hline Thinned D & 5325 & 8.5 & 8.3 & 30.0 & 20.1 & 107.2 & 3531 & 10.5 & 27.6 \\
\hline Thinned D & 5300 & 9.1 & 8.6 & 34.5 & 23.9 & 126.5 & 3550 & 12.7 & 35.7 \\
\hline Thinned E & 5394 & 9.0 & 8.8 & 34.3 & 23.0 & 124.3 & 4063 & 17.2 & 52.4 \\
\hline Thinned E & 4913 & 9.4 & 8.9 & 33.9 & 26.3 & 129.2 & 3719 & 16.9 & 52.4 \\
\hline
\end{tabular}

$N$ : stem number per hectare; $\mathrm{Dg}$ : quadratic mean diameter $(\mathrm{cm}) ; \mathrm{Hg}$ mean height $(\mathrm{m}) ; G$ : basal area $\left(\mathrm{m}^{2} \mathrm{ha}^{-1}\right) ; B m$ : biomass of mean tree $(\mathrm{kg}$ tree $\left.{ }^{-1}\right) ; B T$ : total biomass $\left(\mathrm{t} \mathrm{ha}^{-1}\right)$.

corresponding to a reduction of more than $75 \%$ of the initial number of trees).

In the control treatment, the stand density is quite high with more than 4000 trees ha ${ }^{-1}$ and a basal area greater than $35 \mathrm{~m}^{2} \mathrm{ha}^{-1}$, inducing a mortality rate of 3.2 to $3.6 \%$. On the contrary, after thinning, the mortality rates in thinned plots are very low (0-1\%).

Before thinnings there are significant differences between treatments only for mean tree size but not for the other variables such as stand density, basal area or total height. The analysis of variance for each inventory shows statistical differences among treatments for mean diameter, current and relative increment of $D g$ ( $I c D g$ and $r D g$ respectively) and mean biomass per tree, with higher growth in the heaviest thinning (Tab. V).

The possible effect of thinning on stand yield was studied by comparing the basal area and biomass of the total crop for the different treatments (Tabs. III and IV) but no significant differences (at a 5\% level) were found in both variables. The same result was obtained for current and mean basal area and stem biomass increments (no significant differences between treatments), which are the variables that really reflect the actual yield of the stand for each growth interval (Tab. VI). Thus, for instance, in the whole period (1994-2002) the current basal area increments are higher for thinned than unthinned plots.

The technical effect on stand parameter produced by thinning is clearly shown by comparing the mean tree values before and after thinning, while the response of tree to the thinning treatments is shown through the evolution of the variables over time. At the beginning of the experiment, the mean tree was larger in the control treatment, but after thinning and through the three inventories, the smallest mean tree was found in the control treatment, the mean size in $\mathrm{dbh}$ and biomass of trees increasing significantly with the thinning intensity (Tabs. III and IV).

In Figure 2, the mean horizontal and vertical stand structures are represented for each treatment and for the different inventories. In this figure, we can observe the evolution with time of the diameter classes for each treatment. In the case of vertical structure, only the height at the last inventory was represented

Table IV. Evolution of the main stand variables per treatment and estimation of the natural mortality: C - light thinning; D - moderate thinning; E - heavy thinning.

\begin{tabular}{|c|c|c|c|c|c|c|c|c|c|c|c|c|}
\hline \multirow{2}{*}{ Treatment } & \multirow{2}{*}{ Age } & \multicolumn{6}{|c|}{ Main crop after thinning } & \multicolumn{3}{|c|}{ Natural mortality } & \multicolumn{2}{|c|}{ Total crop } \\
\hline & & $N$ & $D g$ & $H g$ & $G$ & $B m$ & $B T$ & $N$ & $G$ & $B T$ & $G$ & $B T$ \\
\hline \multirow{3}{*}{ Unthinned } & 30 & 4325 & 10.4 & 7.7 & 36.6 & 34.1 & 147.1 & & & & 36.6 & 147.1 \\
\hline & 34 & 3703 & 11.4 & 8.4 & 37.6 & 42.9 & 158.4 & 622 & 1.9 & 4.9 & 39.4 & 163.2 \\
\hline & 38 & 3231 & 12.5 & 9.0 & 39.4 & 54.6 & 175.5 & 472 & 1.8 & 5.1 & 43.1 & 185.8 \\
\hline \multirow{3}{*}{ Thinned C } & 30 & 1941 & 12.6 & 11.1 & 24.2 & 52.8 & 102.2 & & & & 32.9 & 125.3 \\
\hline & 34 & 1938 & 13.1 & 11.1 & 26.0 & 58.4 & 112.9 & 3 & 0.0 & 0.1 & 34.7 & 135.8 \\
\hline & 38 & 1925 & 14.0 & 11.5 & 29.5 & 69.1 & 133.5 & 13 & 0.1 & 0.3 & 38.2 & 156.6 \\
\hline \multirow{3}{*}{ Thinned D } & 30 & 1772 & 12.2 & 10.8 & 20.7 & 47.1 & 85.3 & & & & 32.3 & 116.8 \\
\hline & 34 & 1766 & 13.0 & 10.9 & 23.5 & 57.0 & 100.8 & 6 & 0.0 & 0.1 & 35.1 & 132.4 \\
\hline & 38 & 1766 & 14 & 11.4 & 27.1 & 68.9 & 121.4 & & & & 38.7 & 153.2 \\
\hline \multirow{3}{*}{ Thinned E } & 30 & 1263 & 13.1 & 11.4 & 17.1 & 59.1 & 74.3 & & & & 34.1 & 126.9 \\
\hline & 34 & 1209 & 14.2 & 11.5 & 19.2 & 72.9 & 87.7 & 53 & 0.5 & 1.8 & 36.7 & 141.1 \\
\hline & 38 & 1206 & 15.3 & 11.9 & 22.3 & 89.1 & 106.8 & 3 & 0.1 & 0.2 & 39.8 & 161.4 \\
\hline
\end{tabular}

For thinned plots, at for the first inventory (30-years-old) the basal area and biomass removed with thinning are added to standing values to calculate the total crop of the stand. In the other two inventories the natural mortality is also included in total crop of the stand. $N$ : stem number per hectare; $D g$ : quadratic mean diameter $(\mathrm{cm}) ; \mathrm{Hg}$ : mean height $(\mathrm{m}) ; G$ : basal area $\left(\mathrm{m}^{2} \mathrm{ha}^{-1}\right) ; B m$ : biomass of mean tree $\left(\mathrm{kg}\right.$ tree $\left.{ }^{-1}\right) ; B T$ : total biomass $\left(\mathrm{t}\right.$ ha $\left.{ }^{-1}\right)$. 
Table V. Analysis of variance and Duncan's test of differences among means for quadratic mean diameter $(D g)$, current increment of quadratic mean diameter $(I c D g)$, relative increment of quadratic mean diameter $(r D g)$ and biomass of mean tree $(B m)$. Treatments: A - control; C - light thinning; D - moderate thinning; E - heavy thinning.

\begin{tabular}{|c|c|c|c|c|}
\hline \multirow{2}{*}{ Variables } & \multirow{2}{*}{ Time } & \multicolumn{3}{|c|}{ Inventories $^{1}$} \\
\hline & & 1994 & 1998 & 2002 \\
\hline \multirow[t]{2}{*}{$D g$} & Before thinning & $\mathrm{A} \quad \mathrm{CDE}^{*} \mathrm{~A}$ & $\underline{\mathrm{EC}} \quad \underline{\mathrm{CD}} \quad \mathrm{A}^{*}$ & $\underline{\mathrm{EDC}} \underline{\mathrm{DCA}}^{*}$ \\
\hline & After thinning & $\underline{E C D} \quad A^{*}$ & & \\
\hline$I c D g$ & After thinning & & $\underline{\mathrm{ED}} \underline{\mathrm{CA}^{*}}$ & $\underline{\text { EDC }} \mathrm{A} *$ \\
\hline$r D g$ & After thinning & & $\underline{\mathrm{ED}} \mathrm{CA}^{*}$ & $\underline{E D C} \quad A^{* *}$ \\
\hline \multirow[t]{2}{*}{$B m$} & Before thinning & $\mathrm{A} \mathrm{CDE}^{*}$ & $\underline{\mathrm{EC}} \underline{\mathrm{CD}} \underline{\mathrm{DA}^{*}}$ & $\underline{\mathrm{EDC}} \underline{\mathrm{DCA}}^{*}$ \\
\hline & After thining & $\underline{\mathrm{ECD}} \underline{\mathrm{DA}}^{*}$ & & \\
\hline
\end{tabular}

${ }^{1}$ Underline means there are not significant differences between treatments; * significant at $5 \%$; $*$ significant at $1 \%$. The treatments order is given by Duncan's test.

Table VI. Mean basal area, stem biomass, basal area increment and stem biomass increment of $Q$. pyrenaica stand for unthinned and thinned treatments ( $\mathrm{C}$ - light thinning; $\mathrm{D}$ - moderate thinning; $\mathrm{E}$ - heavy thinning).

\begin{tabular}{|c|c|c|c|c|c|c|}
\hline \multirow{3}{*}{ Treatments } & \multicolumn{3}{|c|}{ Year } & \multicolumn{3}{|c|}{ Period } \\
\hline & 1994 & 1998 & 2002 & 1994-1998 & $1998-2002$ & 1994-2002 \\
\hline & \multicolumn{3}{|c|}{ Basal area $\left(\mathrm{m}^{2} \cdot \mathrm{ha}^{-1}\right)$} & \multicolumn{3}{|c|}{ Basal area increment $\left(\mathrm{m}^{2} \mathrm{ha}^{-1} \mathrm{yr}^{-1}\right)$} \\
\hline Unthinned & 36.6 & 37.6 & 39.4 & 0.25 & 0.45 & 0.35 \\
\hline Thinned C & 24.2 & 26.0 & 29.5 & 0.45 & 0.88 & 0.66 \\
\hline Thinned D & 20.7 & 23.5 & 27.1 & 0.70 & 0.90 & 0.80 \\
\hline \multirow[t]{2}{*}{ Thinned E } & 17.1 & 19.2 & 22.3 & 0.52 & 0.78 & 0.65 \\
\hline & \multicolumn{3}{|c|}{ Stem biomass $\left(\mathrm{t} \cdot \mathrm{ha}^{-1}\right)$} & \multicolumn{3}{|c|}{ Stem biomass increment $\left(\mathrm{t} \mathrm{ha}^{-1} \mathrm{yr}^{-1}\right)$} \\
\hline Unthinned & 147.1 & 158.4 & 175.5 & 2.83 & 4.28 & 3.55 \\
\hline Thinned C & 102.2 & 112.9 & 133.5 & 2.68 & 5.15 & 3.91 \\
\hline Thinned D & 85.3 & 100.8 & 121.4 & 3.88 & 5.15 & 4.51 \\
\hline Thinned E & 74.3 & 87.7 & 106.8 & 3.35 & 4.78 & 4.06 \\
\hline
\end{tabular}

by diameter classes, due to the lack of height growth response to thinning. Although the same sample of trees was used to measure height for each inventory, we did not find relation between growth height and treatments.

The diameter distribution is also more regular for the thinned plots, with few trees in the smallest diameter classes. The presence of more trees in the middle diameter classes in the control plot than in the thinned ones is due to initial differences in diameter distributions of plots.

\section{DISCUSSION AND CONCLUDING REMARKS}

Quercus pyrenaica showed a positive growth response to thinning, as evidenced by enhanced growth rates for stem diameter, and for relative increments of basal area and stem biomass. Similar results were found by Ducrey and Toth [11] and Mayor and Roda [20] in holm oak coppice, where moderate thinning treatments yielded a mean diameter increment of 1.50 and $1.43 \mathrm{~mm}$ year $^{-1}$ respectively.
$Q$. pyrenaica responded to thinning differently according to tree size. In absolute terms, growth of large stems was stimulated by thinning more than that of smaller trees. Large trees probably have a greater capacity for resources acquisition, and are thus more able to take advantage of the increase of resources availability that takes place after thinning, and to eventually use these resources for growth. Similar results were obtained by Mayor and Roda [20], Ducrey and Toth [11] and Cartan-Son et al. [5]. In these cited studies the annual radial growth is positively correlated with diameter size and differences between diameter classes were statistically significant for the study period. More specifically, a higher capacity for canopy expansion, more vigorous branches, and higher uptake of water and nutrients from a larger root system are probably involved in this response.

The larger increment in mean diameter is clearly related to the development of tree crowns, which would mean a strong increment in acorn yield [16, 23, 31], which is necessary for sexual regeneration and for a possible genetic renewal of the stand; although the studies developed at these plots on litter fall 

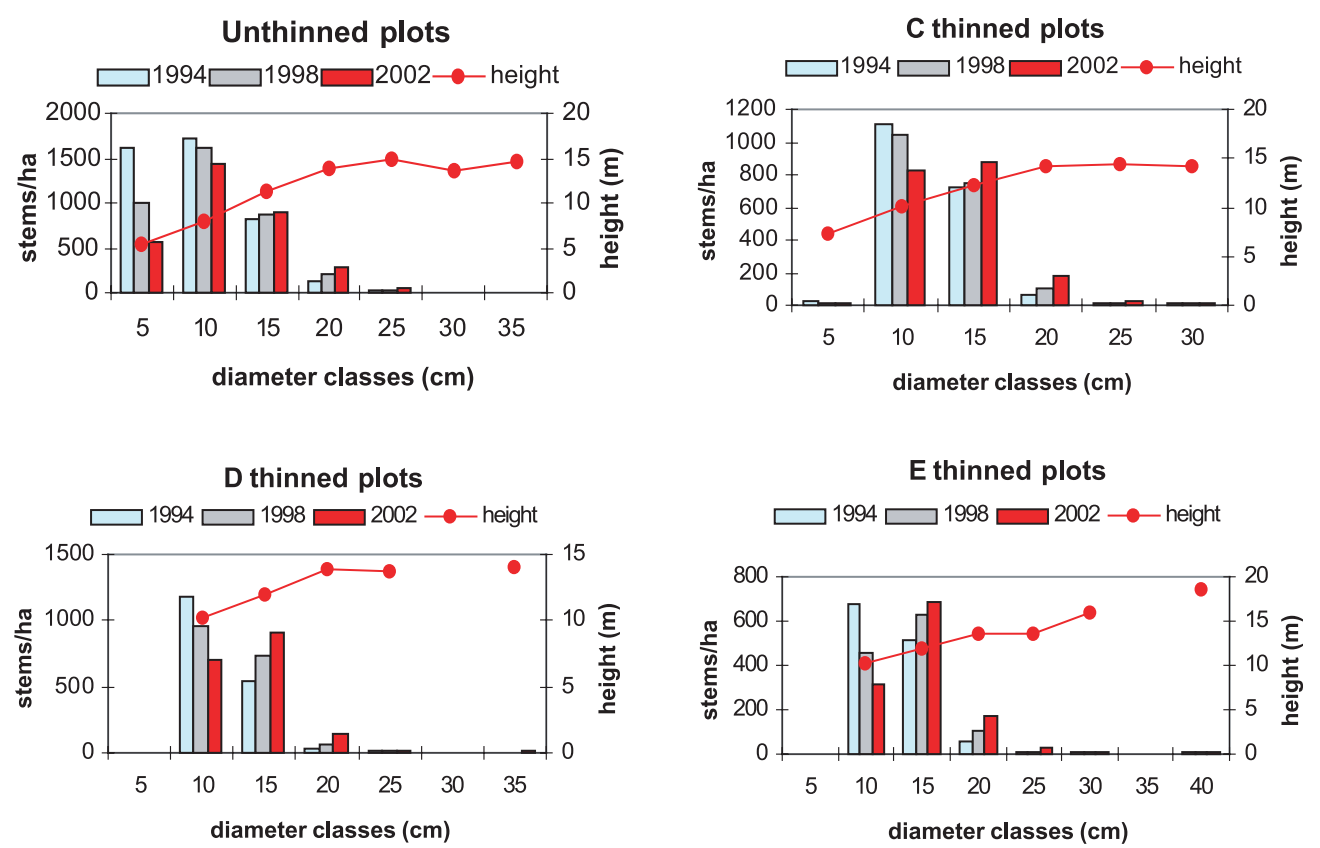

Figure 2. Diameter distribution and height development by treatment at different inventory dates.

in 1996 and 1997 show that acorn yield is scarce in this stand [4], both the acorn yield increment and sexual regeneration are essential to allow the conversion into high forest.

Growth response to thinning was strong for each time intervals. Stem diameter increments were higher for thinned than for unthinned plots and were higher during the second period (1998-2002) than during the first one; these results do not agree with others like these obtained by Mayor and Roda [20] with Quercus ilex, which show an opposite trend probably due to climatic conditions during the experiment.

The positive effects of thinning have proved to be more evident during the first ten years after thinning and to decrease with the progressive closure of canopy cover. Some authors $[8,20]$ found that perennial and deciduous oaks showed growth responses to thinning until 10-12 years after thinning, with growth rates falling afterwards to pre-thinning values. Besides, Cutter et al. [8] observed a 10-12-year-period of significantly higher growth for two oak species, but for one of them this period took place immediately after thinning while for the other one a lag of 6-7 years after thinning preceded growth increase. In our case, eight years after thinning, growth is still boosted, and then more time is required to determine the optimal thinning rotation for this coppice stand. In order to define silvicultural system based in well established ecological consideration for the management of $Q$. pyrenaica stands, further investigations should consider the interactions between thinning intensities and site conditions (site quality), the duration and the consistence of changes induced by thinning and they should also assess the responses to thinning at the whole stand level [7,10, 12].

In coppices, similar results have been reported in the literature, both for diameter and height. Lampson [18] found that thinning improved diameter growth of stump sprouts five years after treatment in Appalachian hardwoods. Roth [24] established that thinning increased the diameter growth by 31 to $69 \%$. However, in both studies, height appeared unaffected by thinning, as it was the case in our study. A slight height growth increase was only observed for the largest trees.

Absolute rates of stand growth, as basal area and total biomass increments, are unaffected by thinning during the studied time intervals. This is in accordance with the law of constant final yield (the so-called Eichorn's law), which states that over a wide range of densities, total yields stay the same. Thus, forest yield is relatively constant among thinning intensities [1]. The differences founded in total basal area and biomass between treatments are due to the initial differences between plots (number of trees/ha and mean diameter). The yield reduction by thinning is compensated by the positive effect of intensive low thinning on diameter, resulting in larger size tree. This regime also produces noticeable improvement in the vigour of the stand and its resistance to abiotic damage.

In non Mediterranean stands of Quercus species, such as $Q$. petraea Liebl., Assmann [1] reported a low reduction of yield growth with heavy thinning (50\% of the basal area removed). Nonetheless, in other thinning experiments carried out in coppices of Mediterranean oaks ( $Q$. faginea and $Q$. pyrenaica) that showed a significant initial stagnation of the stand, the thinned plots presented a higher basal area growth than the control [2, 3]. This fact reveals the urgency of the necessary actions that forest managers should start up, through thinning or alternative silvicultural treatments, in abandoned Mediterranean coppice stands.

With regard to the role of thinning, besides the benefits on the growth of residual trees, some changes in physiological functioning of trees have been observed. Despite similar daily 
seasonal patterns, xylem water potential, stomatal conductance and transpiration rates were higher in the thinned plots [7]. This can be explained by considering that thinning increases the availability of resources for residual trees, namely water, by reducing the competition above and below ground level, i.e. the stand transpiring surface, the live root density within the soil and the improvement of radiation for the lower part of tree crowns.

The new stand structure obtained after thinning shows clear advantages for stands facing the problems of coppices. With a lower stand density, the horizontal structure presents better conditions for fire prevention (less coarse woody debris and less biomass), as well as non continuous canopies (vertical structure) from the soil vegetation or under-story shrubs. The gaps that are created in the horizontal structure also favour the objectives for coppice stands through the improvement of the silvopastoral production or the recreational and landscape values of the stands. The high natural mortality rate in control plots reflects a strong competition among trees, which reduces their vigour and the site resources dedicated to flowering and fruiting [29]. Furthermore, the presence of dead trees in stands increases the risk of forest fires [6, 9, 13]. However, in this experiment, with good site quality, stand stagnation has not been observed in the control plot as usual problem in the region in Q. pyrenaica stands [28].

Although the analyses and evaluation of the production of epicormic sprouts along the trunks in relation to thinning treatment were not an objective of this work, differences in stumps and stem sprouts between treatments were not observed. However, we should bear in mind that the experimental plots were not fenced and then could have been grazed by livestock [15].

To recover abandoned Mediterranean coppice stands, common silvicultural practices consider conversion from coppice to high forest as the best alternative, but another possibility is to re-adopt and improve traditional coppice management. The choice depends on the local socio-economic frame. Dealing with the rare studies the dynamics of $Q$. pyrenaica stands no longer advise conversion to high forests. The main reason lies in their low productivity as compared, for example, with other hardwood species, their low growth response to thinning and in the timber price situation within the Mediterranean region. The authors $[2,16,19]$ advise keeping the coppice stands on very poor or degraded soils because pre-commercial thinning of oak stump sprouts does not have economical benefits while the ecological improvement of such stands is very low. But the positive responses observed here with thinning and the ecological value of such coppice stands justify the development of these silvicultural treatments on good sites to improve their structure and stability and reduce the risk of fire and degradation.

Acknowledgements: We thank A. Bachiller and E. Garcia for plots installation and data collection.

\section{REFERENCES}

[1] Assmann E., Principles of Forest Yield Study, Pergamon Press, Oxford, 1970

[2] Cañellas I., Montero G., Ortega C., Torres E., Transformación del monte bajo de quejigo (Quercus faginea Lamk.) a monte adehesado por claras de diferente intensidad, Primeros resultados, in: Pascoa et al. (Eds.), Los Recursos Forestales en Desarrollo Rural, Vol. I, 1994, pp. 163-170.

[3] Cañellas I., Montero G., San Miguel A., Montoto J.L., Bachiller A., Transformation of rebollo oak coppice (Quercus pyrenaica Willd.) into open woodlands by thinning at different intensities, Preliminary results, Investig. Agrar. Sist. Recur. For. Fuera de serie 3 (1994) $71-78$.

[4] Cañellas I., Montero G., Jiménez M.D., Litter fall in rebollo oak (Quercus pyrenaica Willd.) coppice thinned with various intensities, Ann. Ist. Sper. Selvic. 27 (1996) 25-29.

[5] Cartan-Son M., Floret C., Galan M.J., Grandjanny M., Le Floc'h E., Maistre M., Perret P., Romane F., Factors affecting radical of Quercus ilex L., in a coppice stand in southern France, Vegetatio 99-100 (1992) 61-68.

[6] Carvalho J., Loireiro A., Stool and root resprouting according to different cutting seasons in a Quercus pyrenaica Willd. coppice, Annali Istituto Sperimentale Selvicoltura 27 (1996) 83-88.

[7] Cutini A., Mascia V., Silvicultural treatment of holm oak (Quercus ilex L.) coppices in Southern Sardinia: effects of thinning on water potential, transpiration and stomatal conductance, Ann. Ist. Sper. Selvic. 27 (1996) 65-70.

[8] Cutter B.E., Lowell K.E., Dwyer J.P., Thinning effects on diameter growth in black and scarlet oak as shown by tree ring analyses, For. Ecol. Manage. 43 (1991) 1-13.

[9] Ducrey M., Quelle sylviculture et quel avenir pour les taillis de chêne vert (Quercus ilex $\mathrm{L}$.) de la région méditerranéenne française, Rev. For. Fr. XLIV (1992) 12-33.

[10] Ducrey M., Boisserie M., Recru naturel dans des taillis de chêne vert (Quercus ilex L.) à la suite d'exploitations partielles, Ann. Sci. For. 49 (1992) 91-109.

[11] Ducrey M., Toth J., Effect of cleaning and thinning on height growth and girth increment in holm oak coppices (Quercus ilex L.), Vegetatio 99/100 (1992) 365-376.

[12] Ducrey M., Turrel M., Influence of cutting methods and dates on stump sprouting in holm oak (Quercus ilex L.) coppice, Ann. Sci. For. 49 (1992) 449-464.

[13] Johnson P.S., Shifley S.R., Rogers R., The ecology and silviculture of oaks, CABI Publishing, 2002.

[14] Flewelling J.W., Pienaar L.V., Multiplicative regression with lognormal errors, For. Sci. 27 (1981) 281-289.

[15] Fontaine F., Colin F., Jarret P., Druelle J.L., Evolution of the epicormic potential on 17-year-old Quercus petraea trees: first results, Ann. For. Sci. 58 (2001) 583-592.

[16] Gracia M., Retana J., Effect of site quality and thinning management on the structure of holm oak forests in northeast Spain, Ann Sci. For. 53 (1996) 571-584.

[17] Guérard N., Barthélémy D., Cabanettes A., Courdier F., Trichet P., Willm J., Influence de la compétition herbacée sur la croissance et l'architecture de jeunes chênes rouges d'Amérique (Quercus rubra L.) en plantation, Ann. For. Sci. 58 (2001) 395-410.

[18] Lampson N.I., Precommercial thinning and pruning of Appalachian stump sprouts 10 year results, South. J. App. For. 12 (1988) 23-27.

[19] Luisi N., Manicone R., Oak decline in southern Italy: attempts to control it, Italia Forestale e Montana 46 (1991) 341-356.

[20] Mayor X., Roda F., Growth response of holm oak (Quercus ilex L.) to commercial thinning in the Montseny mountains (NE Spain), Ann. Sci. For. 50 (1993) 247-256.

[21] Moser E.B., Saxton A.M., Pezeshki S.R., Repeated measures analysis of variance: application to tree research, Can. J. For. Res. 20 (1990) 524-535.

[22] Rivas Martínez S., Mapa de las series de vegetación de España y su memoria, ICONA, Madrid, 1986.

[23] Roda F., Retana J., Gracia C., Bellot J., Ecology of Mediterranean evergreen oak forests, Ecological Studies 137, Springer, 1999.

[24] Roth E.R., Decay following thinning of sprout oak clumps, J. For. 59 (1956) 26-30. 
[25] San Miguel A., Inventario de la vegetación herbácea en montes de Quercus pyrenaica Willd. Diseño e intensidad de muestreo, An. Inst. Nac. Invest. Agrar. Ser. For. 7 (1983) 55-66.

[26] San Miguel A., Cañellas I., Montero G., Serrada R., Situación actual de la investigación forestal sobre las especies mediterráneas del género Quercus en España, IUFRO XX Congress, Tampere, Finland, 1995.

[27] Sas Institute Inc. Sas/Stattm User's guide, Release 6.03 Edition, Cary, USA, 1988.

[28] Serrada R., Allué M., San Miguel A., The coppice system in Spain. Current situation, state of art and major areas to be investigated, Ann. Ist. Sper. Selvic. 23 (1992) 266-275.
[29] Serrada R., González I., López Peña C., Marchal B., San Miguel A., Tolosana E., Dasometric classification and alternative silvopastoral uses of rebollo oak (Quercus pyrenaica Willd.) stands in Madrid (Spain). Design for a pilot project, Investig. Agrar. Sist. Recur. For. Fuera de Serie 3 (1994) 79-88.

[30] Zulueta De J., Recherches en vue de l'amélioration des pâturages dans les forêts de $Q$. pyrenaica et $Q$. faginea en Espagne, For. Méditerr. 3 (1981) 58-61.

[31] Zulueta De J., Montero G., Posibilidades de mejora silvopascícola en montes bajos de quejigo (Quercus faginea Lamk). Efecto de los aclareos en la producción de bellota, An. Inst. Nac. Invest. Agrar. Ser. For. 6 (1982) 75-87. 